\title{
Development of Learning Module Based on Discovery Learning Using Probing Prompting Techniques in Redox Reactions to Improve Critical Thinking Ability in Class X Students
}

\author{
Rusdani $^{1,3}$, Hardeli $^{2}$, Budhi Oktavia ${ }^{2}$, Syamsi Aini ${ }^{2}$, \\ ${ }^{1}$ Magister Student of Chemical Education Padang State University \\ ${ }^{2}$ Lecturer in Chemistry at Padang State University \\ ${ }^{3}$ Chemistry teacherat SMAN 9 Padang
}

\begin{abstract}
This study aims to produce a chemical module based on discovery learning redox reactions using probing prompting techniques and determine the level of validity, practicality and effectiveness of the module. This research includes education development research (EDR) using the Plomp development model which has three stages, namely the preliminary research phase, the prototyping phase and the assessment phase. At the prototyping stage, self evaluation is carried out, expert review, one-to-one evaluation, small group evaluation, while the assessment stage is carried out through field tests. in two schools namely SMAN 15 Padang and SMAN 9 Padang. The research instrument used was a questionnaire in the form of validity and practicality sheets, multiple choice questions and critical thinking questions. Results Module validity by an average validator is 0.87 with a very high validity category. The results of practicality by students in small groups an average of 0.93 and practicality by teachers on field tests an average of 0.87 with a very high level of practicality. Hypothesis test results showed a significant difference between the learning outcomes of experimental class students and the control class in schools with moderate and low ability to use modules. Hypothesis test results also showed a significant difference between the critical thinking skills of experimental class students and the control class both in medium and low ability schools on the use of modules.
\end{abstract}

Keywords:- Modules, Redox Reactions, Discovery, Probing Promting Techniques, Critical Thinking, Plomp Development Models.

\section{INTRODUCTION}

The learning process is a communication process that occurs between teachers and students. The learning process can be said to be successful if students achieve the expected competence, and is a reflection of the ability of students in terms of understanding the subject matter. When the learning process takes place in addition to thinking the attention of students in learning is also a very important thing to note so that the knowledge being explained can be understood properly. The learning process is not memorization. Students must understand a knowledge so they can easily recall it (Silbermen, 2006). By learning students can show that there is a change in behavior that relatively occurs due to some experience that has been experienced and exercises that have been done before. Learning is a cognitive process, the process is more important than the results of learning itself (Bower, 1987: 150).

The school is a place of interaction between teachers and students. Learning is a help given by teachers to students for the acquisition of knowledge, mastery of skills and behavior and the formation of attitudes in students. Teachers in learning are one of the factors in the success of educational endeavors. The teacher is responsible for organizing, directing, and creating an atmosphere that encourages students to be active in carrying out learning activities in class. The importance of the teacher's role in learning is inseparable from the teacher's ability to convey subject matter to students. A concept will be easily understood and remembered by students if the concept is presented through interesting learning procedures and steps.

One of the subjects taught in high school is Chemistry. Chemistry is the study of matter and the changes that require it (Chang, 2010: 4). Chemistry has an abstract concept arranged through deductive reasoning that requires gradual and continuous understanding. Understanding the concept is the initial step taken to move to the next stage, namely the application of understanding. However, many students who have not been able to master the concepts taught. This is due to the use of strategies or learning techniques that are not appropriate in learning.

Students in the learning process are expected to understand well the material being taught so that learning objectives can be achieved to the maximum. Difficulties experienced by students in understanding chemistry subjects are generally caused by chemistry subjects containing concepts that are difficult to be understood by students and also because chemistry lessons involve chemical reactions, calculations and many relate to abstract concepts (columnuc, 
$2011: 84-101)$. Teachers need to help and direct students to build their knowledge actively and correctly during the learning process by encouraging them to participate in various learning activities.

Probing prompting is a learning technique presented by the teacher by giving questions that are probing and guiding students so that a thought process occurs that can link students' knowledge and experience with new knowledge that is being learned. Probing prompting learning techniques can also be said as learning that refers to increasing students' thinking power to be more active, and able to develop the ability to express opinions for students so that their knowledge becomes wider (Shoimin, 2014: 126).

Probing prompting learning technique is also learning that is able to develop and improve students' critical thinking skills, because in the learning process students are directly involved. Students are given a series of questions ranging from simple questions to questions with a higher level that connects students' knowledge and experience with new knowledge being learned. The questions given to students can lead students to always think and develop their thinking skills to be higher and build their own knowledge so that students can understand the subject matter well. The ability to think at a higher level is critical thinking ability (Elsa, 2015: 2)

Critical thinking is an organized process that allows students to evaluate the evidence, assumptions, logic and language that underlies the statements of others. By thinking critically students can find various truths among the many events and sources of information they receive. Students are given the opportunity to use the mind in a higher level of thinking, so students are accustomed to using arguments and evidence that is accurate and can be accounted for and logic that makes sense (Johson, 2002: 184). Students' critical thinking skills can be developed by teaching students how to find answers to questions or problems in an objective and open mind, then teaching students to investigate what is causing an event (Lang, 2006: 461). The critical thinking process of students can be trained through the learning process using concepts that are applied to real life situations through critical thinking by deepening the quality of students' understanding to apply prior knowledge to new situations encountered (Zivkovic, 2016: 107).

The learning process requires teaching materials as supporting media for activities. The success of the learning process is largely determined by the selection of teaching materials or appropriate learning methods (Isworini, 2015). There are three reasons that cause the need for the development of teaching materials, namely the availability of teaching materials in accordance with the demands of the curriculum, the characteristics of the target and the demands of learning problems (Ministry of National Education, 2008: 8 ), one of the teaching materials that can be developed is a module. Learning using modules makes students more independent (Directorate of Education Personnel, 2008: 3), learning activities are planned to help students achieve a number of goals that have been specifically and clearly formulated (Nasution, 2015: 205) and the level of students' mastery of the material discussed in the module can be measured by students themselves (Prastowo, 2014: 209). The use of modules for students can increase their motivation to learn because the module has been equipped with concept maps, charts and colorful images. The concept map contained in the module can be used as a reminder of information, focusing attention and increasing students' understanding of the concept of the lesson. Colored charts and pictures make the brain more active and increase students' enjoyment (Ellizar et al, 2013).

Based on interviews with several chemistry teachers, the results of the questionnaire to students found various problems in learning chemistry. First, time limitations in the even semester such as the Ramadhan pesantren and fasting holidays that fall in the effective month of learning so that teachers lack effective weeks which usually amounts to 22 weeks to 16 weeks so that teachers tend to pursue the material and prefer to use the lecture method and give independent assignments to students. This has an impact on the understanding and application of learners' concepts to the redox reaction material to decrease. From the same source also obtained information on the daily value of students for redox reaction material in class X MIA 4 and X MIA 5 in SMA 15 Padang, which has not yet reached the KKM (Minimum completeness criteria). Second, the use of probing prompting based learning techniques is still not maximally applied to the learning process at school. Third, teaching materials used in the learning process have not been effective in supporting the implementation of the learning process based on the 2013 revised 2017 curriculum. Fourth, students have difficulty in working on questions on the redox reaction material. In general, the difficulty experienced is in solving problems that require a lot of understanding of concepts and rules in determining oxidation numbers. Based on the results of tests of critical thinking questions given to several students, it was found that the students' critical thinking skills were still in the sufficient category.

Discovery learning-based learning modules using probing prompting techniques can be an alternative to solving these problems. The module is equipped with teaching material that contains questions that guide students to think critically which are facilitated and motivated by the teacher in learning.

\section{RESEARCH METHOD}

This type of research is education development research (EDR). In this research, the development of discovery learning redox reaction module based on discovery learning using probing prompting technique to improve the critical thinking skills of high school students in class X. The development model used in this study uses the Plomp model design as developed by Tjeerd Plomp. This model consists of 3 stages, namely preliminary research (preliminary research), the stage of developing or making a 
ISSN No:-2456-2165

prototype (development or prototyping phase) and the assessment phase (Plomp, 2013: 30).

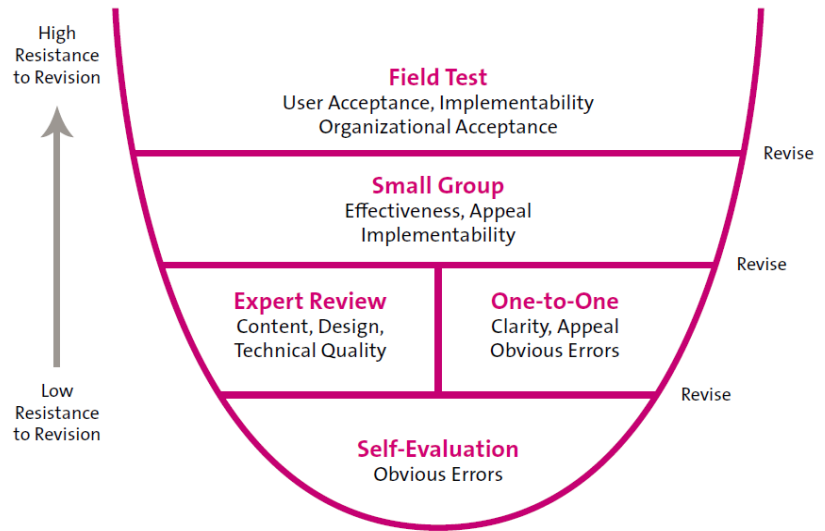

Picture 1.

Fomative Evaluation Layer (Plomp, 2013: 36)

Based on Picture 1 the formative evaluation layers used in this study are as follows:

1. Self-evaluation, using a checklist of important characteristics or design specifications.

2. Expert reviews, expert groups (subject matter experts, learning design experts) provide assessments and suggestions for the products being developed.

3. Individual evaluation (one-to-one evaluation), three users use the product in normal situations. Evaluators observe and interview respondents.

4. Small or micto evaluation, a small group of users using the product in normal situations. Evaluators observe and interview respondents.

5. Field trials (group tests), a group of users use the product in actual conditions to find out the practicality and effectiveness of the product.

The research design used was the research "Non Equivalent Control Group Postest Only Design". This design can be described as the following table (Lutfi, 2005: 69).

\begin{tabular}{|c|c|c|}
\hline & Treatment & Final Test \\
\hline Experiment Class & $\mathrm{X}$ & $\mathrm{T}$ \\
\hline Control Class & $\mathrm{Y}$ & $\mathrm{T}$ \\
\hline
\end{tabular}

Table 1:- Design of Field Trial Execution

Information:

X: Learning with modules

Y: Learning without modules

Q: Final Test

Analysis of critical thinking skills is done by giving a score on the answers given. Scoring is based on the assessment rubric which is modified from the following Finken and Ennis (Zubaidah, 2015: 211).

\begin{tabular}{|c|c|}
\hline $\begin{array}{c}\text { Scores / } \\
\text { Points }\end{array}$ & Descriptors \\
\hline 5 & $\begin{array}{l}\text { - All concepts are true, clear and specific } \\
\text { - All answers are correct, clear and specific, } \\
\text { supported by strong, true, clear arguments } \\
\text { - Flow of good thinking, all concepts are } \\
\text { interrelated and integrated } \\
\text { - Grammar is good and right } \\
\text { - All aspects appear, evidence is good and } \\
\text { balanced }\end{array}$ \\
\hline 4 & $\begin{array}{l}\text { - Most concepts are true, clear but lack specificity } \\
\text { - Most of the answers are correct, clear, but lack } \\
\text { specificity } \\
\text { - Good thinking flow, most concepts are } \\
\text { interrelated and integrated } \\
\text { - Grammar is good and right, there are small } \\
\text { mistakes } \\
\text { - All aspects appear, but not yet balanced }\end{array}$ \\
\hline 3 & $\begin{array}{l}\text { - A few concepts are true and clear } \\
\text { - A small part of the answer description is true and } \\
\text { clear but the reasons and arguments are unclear } \\
\text { - The flow of thinking is quite good, a few are } \\
\text { interrelated } \\
\text { - Grammar is quite good, there are spelling } \\
\text { mistakes } \\
\text { - Most aspects that seem right }\end{array}$ \\
\hline 2 & $\begin{array}{l}\text { - Concepts are lacking focus or excessive or dubious } \\
\text { - The description of the answer does not support } \\
\text { - The flow of thinking is not good, the concepts are not } \\
\text { interrelated } \\
\text { - Good grammar, incomplete sentences } \\
\text { - A few aspects that seem right }\end{array}$ \\
\hline 1 & $\begin{array}{l}\text { - All concepts are incorrect or insufficient } \\
\text { - The reason is incorrect } \\
\text { - The flow of thinking is not good } \\
\text { - Grammar is not good } \\
\text { - Overall aspects are insufficient }\end{array}$ \\
\hline 0 & - There are no answers or wrong answers \\
\hline
\end{tabular}




\section{RESULTS}

\section{Description of research}

The effectiveness of the module in terms of learning outcomes seen by comparing the learning outcomes of experimental class students who learn by using modules with the learning outcomes of control class students who do not use modules. The test was conducted at two schools with moderate and low ability of students.

\begin{tabular}{|l|c|c|c|}
\hline \multicolumn{1}{|c|}{ Class } & $\begin{array}{c}\text { Average } \\
\text { pretest }\end{array}$ & $\begin{array}{c}\text { Average } \\
\text { posttest }\end{array}$ & $\begin{array}{c}\text { Average } \\
\text { Gain Score }\end{array}$ \\
\hline Experiment 1 & 20,48 & 74,58 & 54,10 \\
\hline Control 1 & 19,27 & 63,73 & 44,46 \\
\hline Experiment 2 & 26,62 & 78,68 & 52,06 \\
\hline Control 2 & 20,38 & 76,76 & 56,38 \\
\hline
\end{tabular}

Table 3:- Sample Class Learning Outcomes

To determine the effect of the use of modules on student learning outcomes hypotheses are tested. Before testing the hypothesis, a normality and homogeneity test on the sample class is done from the test results of learning outcomes that have been obtained. The results of the normality and homogeneity tests of the sample classes found that the learning outcomes of the experimental class and the control class at both schools were normally distributed and had homogeneous variances, where the significance value> 0.05 , so that the $t$ test was carried out. Hypothesis test results can be seen in the following table:

\begin{tabular}{|c|c|c|c|c|c|}
\hline Class & N & $\mathbf{X}$ & St.Dev & $\begin{array}{c}\text { Asymp. } \\
\text { Sig }\end{array}$ & Decision \\
\hline Experiment 1 & 33 & 74,58 & 9,865 & .000 & Reject $\mathrm{H}_{0}$ \\
\hline Control 1 & 33 & 63,73 & 12,765 & & \\
\hline Experiment 2 & 34 & 78,68 & 8,807 & .000 & Reject $\mathrm{H}_{0}$ \\
\cline { 1 - 3 } Control 2 & 34 & 76,76 & 12,962 & & \\
\hline
\end{tabular}

Table 4:- Hypothesis Test Results for Sample Classes

If the significance value $>0.05$, accept $\mathrm{H}_{0}$ and vice versa. The decision to reject $\mathrm{H}_{0}$ means that the learning outcomes of students with high abilities who learn using modules and without modules differ significantly. The average learning outcomes of students who use modules are higher than students who do not use modules. The decision to accept $\mathrm{H}_{0}$ means that the learning outcomes of students with low ability who study using modules and without modules do not differ significantly. But the average learning outcomes of students who use modules are higher than students who do not use modules.

Whether there is an interaction between the use of discovery learning based redox chemical reaction modules with school level probing prompting techniques in influencing learning outcomes is known from the two-way ANOVA test results in Picture 2, it can be seen that in low category schools the use of modules is very influential on student learning outcomes. Medium category schools using modules have little effect on student learning outcomes, so the use of modules is more suitable for low category schools.

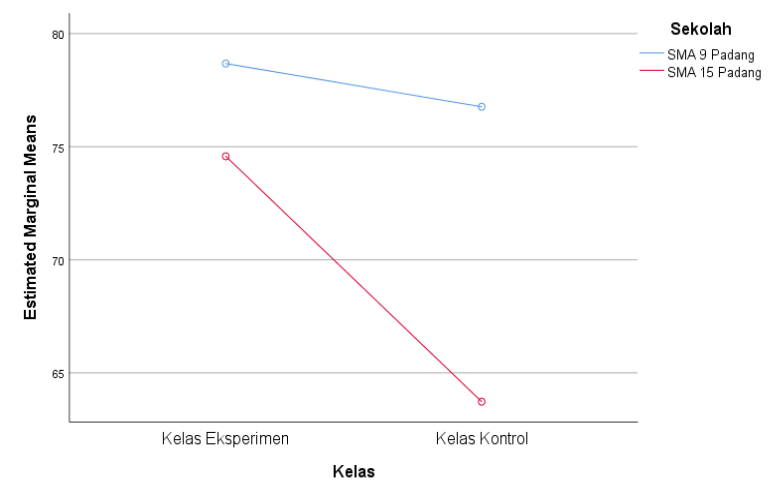

Picture 2.

Interaction between the use of modules and school level in influencing learning outcomes.

The ability to think critically is seen from five aspects, namely providing basic explanations (basic clarification), making the basis of a decision (the bases for a decision), making conclusions (inference), providing advanced clarification and arranging strategies and tactics (strategy and tactics) ). Students' critical thinking skills can be seen from the ability of students to answer questions that are designed based on indicators of critical thinking. Distribution of students' critical thinking skills test scores and data processing can be seen in the following table 5 .

\begin{tabular}{|c|c|c|c|c|c|c|c|c|}
\hline \multirow{3}{*}{$\begin{array}{l}\text { Aspects of Critical } \\
\text { Thinking Skills } \\
\text { Basic Clarification } \\
\end{array}$} & \multicolumn{8}{|c|}{ \% Critical Thinking Skills and Their Categories } \\
\hline & \multicolumn{2}{|c|}{$\begin{array}{l}\text { Experiment } \\
\text { Class } 1\end{array}$} & \multicolumn{2}{|c|}{$\begin{array}{l}\text { Control } \\
\text { Class } 1\end{array}$} & \multicolumn{2}{|c|}{$\begin{array}{l}\text { Experiment } \\
\text { Class } 2\end{array}$} & \multicolumn{2}{|c|}{$\begin{array}{l}\text { Control } \\
\text { Class } 2 \\
\end{array}$} \\
\hline & $91,52 \%$ & Very good & $80,61 \%$ & Very good & $90,59 \%$ & Very good & $81,18 \%$ & Very good \\
\hline The bases for a decision & $71,52 \%$ & Good & $65,45 \%$ & Good & $81,18 \%$ & Very good & $65,88 \%$ & Good \\
\hline Inference & $61,82 \%$ & Good & $49,70 \%$ & Enough & $75,29 \%$ & Good & $61,76 \%$ & Good \\
\hline Advanced Clarification & $43,64 \%$ & Enough & $40,00 \%$ & Less & $60,00 \%$ & Enough & $60,59 \%$ & Good \\
\hline Strategy and tactics & $82,42 \%$ & Very good & $80,00 \%$ & Good & $77,65 \%$ & Good & $58,24 \%$ & Enough \\
\hline Average & $70,18 \%$ & Good & $63,15 \%$ & Good & $76,94 \%$ & Good & $65,53 \%$ & Good \\
\hline
\end{tabular}

Table 5:- Results of data analysis of students' critical thinking skills

To determine the effect of the use of modules on the ability to think critically, a hypothesis test is conducted.
Before testing the hypothesis, a normality and homogeneity test on the sample class is done from the test results of 
ISSN No:-2456-2165

learning outcomes that have been obtained. The results of the normality and homogeneity tests of the sample classes obtained data on the learning outcomes of the experimental class and the control class in the two normally distributed schools where the significance value $>0.05$ and have a nonhomogeneous variance where the significance value $<0.05$, so that the t test '. Hypothesis test results can be seen in Table 6.

\begin{tabular}{|l|c|c|c|c|c|}
\hline \multicolumn{1}{|c|}{ Class } & N & $\mathbf{X}$ & St.Dev & $\begin{array}{c}\text { Asymp. } \\
\text { Sig }\end{array}$ & Decision \\
\hline Experiment 1 & 33 & 17,70 & 3,216 & .046 & \multirow{2}{*}{ Reject $\mathrm{H}_{0}$} \\
\hline Control 1 & 33 & 15.61 & 3,774 & & \\
\hline Experiment 2 & 34 & 18,82 & 3,289 & .005 & \multirow{2}{*}{ Reject $\mathrm{H}_{0}$} \\
\hline Control 2 & 34 & 16,79 & 3,885 & & \\
\hline
\end{tabular}

Table 6:- Hypothesis Test Results for Sample Classes

If the significance value> 0.05 , accept $\mathrm{H}_{0}$ and vice versa. The decision to reject $\mathrm{H}_{0}$ means the critical thinking ability of students who have learned to use modules and without using modules is significantly different. The average critical thinking ability of students using the module learning process is higher than students whose learning process does not use modules.

Whether there is an interaction between the use of discovery learning based redox chemical reaction modules and school level probing prompting techniques in influencing students' critical thinking skills can be seen from the two-way ANOVA test results that can be seen in Figure 3 . Based on Figure 3 it can be seen that in the medium category schools and schools with low categories the use of modules affects the students' critical thinking skills. Medium category students' critical thinking skills are better than low category schools, but the use of modules is equally influential on critical thinking skills.

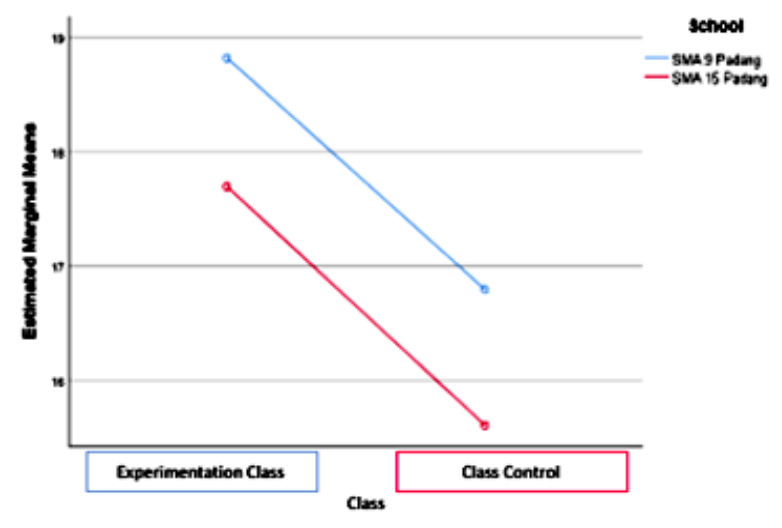

Picture 3.

Interaction between the use of modules and the school level in influencing critical thinking skills

Learning activities of students assessed are activities that use a redox reaction chemistry module based on discovery learning with probing prompting techniques. These activities include visual activities, mental activities and writing activities with a grid of learning activity assessment sheets. Based on the learning activity assessment sheet and the data processing results obtained the analysis of learning activity data in Table 7.

\begin{tabular}{|c|l|c|c|c|c|}
\hline No & Aktivitas & $\begin{array}{c}\text { EC. } \\
\mathbf{1}\end{array}$ & Category & EC.2 & Category \\
\hline 1 & $\begin{array}{l}\text { Observe } \\
\text { pictures and } \\
\text { written } \\
\text { ources to } \\
\text { formulate } \\
\text { problems } \\
\text { and } \\
\text { hypotheses }\end{array}$ & $81,94 \%$ & $\begin{array}{c}\text { Very } \\
\text { Effective }\end{array}$ & $\begin{array}{c}\mathbf{9 4 , 9 1} \\
\mathbf{\%}\end{array}$ & $\begin{array}{c}\text { Very } \\
\text { Effective }\end{array}$ \\
\hline 2 & $\begin{array}{l}\text { Answering } \\
\text { questions in } \\
\text { the module }\end{array}$ & $84,95 \%$ & Effective & $\begin{array}{c}\mathbf{9 3 , 9 8} \\
\mathbf{\%}\end{array}$ & $\begin{array}{c}\text { Effective } \\
\text { Eery }\end{array}$ \\
\hline 3 & $\begin{array}{l}\text { Gathering } \\
\text { Information }\end{array}$ & $85,65 \%$ & $\begin{array}{c}\text { Very } \\
\text { Effective }\end{array}$ & $\begin{array}{c}\mathbf{9 0 , 9 7} \\
\mathbf{\%}\end{array}$ & $\begin{array}{c}\text { Very } \\
\text { Effective }\end{array}$ \\
\hline 4 & $\begin{array}{l}\text { Work on } \\
\text { worksheets }\end{array}$ & $91,44 \%$ & $\begin{array}{c}\text { Very } \\
\text { Effective }\end{array}$ & $\begin{array}{c}\mathbf{9 3 , 9 5} \\
\mathbf{\%}\end{array}$ & $\begin{array}{c}\text { Very } \\
\text { Effective }\end{array}$ \\
\hline
\end{tabular}

Table 7. Results of data analysis of experimental class learning activities

EC.1 $=$ Experiment Class 1

EC.2 $=$ Experiment Class 2

\section{DISCUSSION}

Overall, the average kappa moment acquisition for the validity of a redox reaction-based chemical module based on recovery learning with the probing prompting technique developed was 0.88 with a very high validity category. The module validation results indicate that the module designed is valid. A product is said to be valid if the product can show a condition that is in accordance with the contents and construct (Arikunto, 2015: 66). Content validity (relevance) shows the module components developed based on science (state-of-the-art knowledge) and construct validity (consistency) show that module components are consistently connected with each other (Plomp, 2013: 28)

Overall the average kappa moment acquisition for the practicality of the discovery learning based redox chemical module developed was 0.91 from students (field tests) and 0.86 from teachers with very high levels of practicality. From the results of the practicality of the modules obtained shows that the modules designed are practical. The practicality aspect of the module can be seen in terms of its use which can be used in normal conditions and the developed product can be applied by teachers and students (Nieveen, 1999: 127). 
The use of discovery learning redox chemical modules based on probing prompting can improve students' critical thinking skills. The application of discovery learning based models improves understanding of critical thinking concepts and abilities (Yuliani, 2015). Comparison of the number of sample class students with critical thinking skills is in the category of very good, good, sufficient, less can be seen in Picture 4

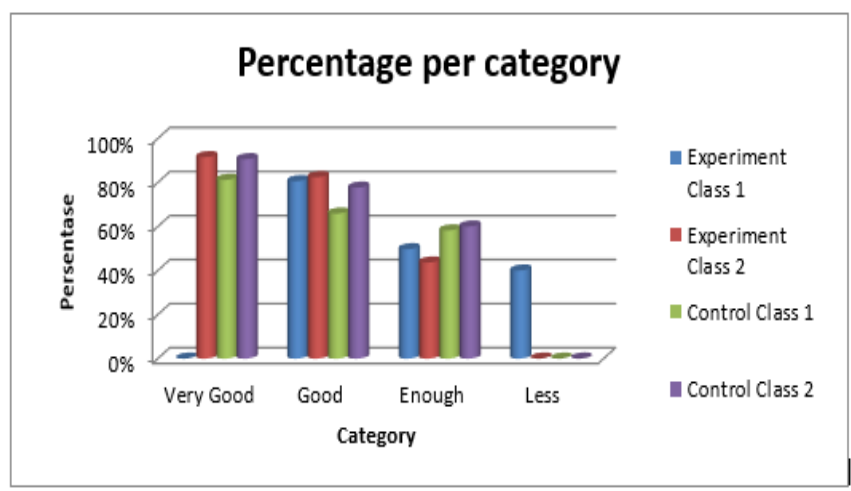

Picture 4.

Percentage of sample class students in each category of critical thinking questions

The results of data analysis of students' critical thinking skills in each aspect of critical thinking skills can be seen in Picture 5.

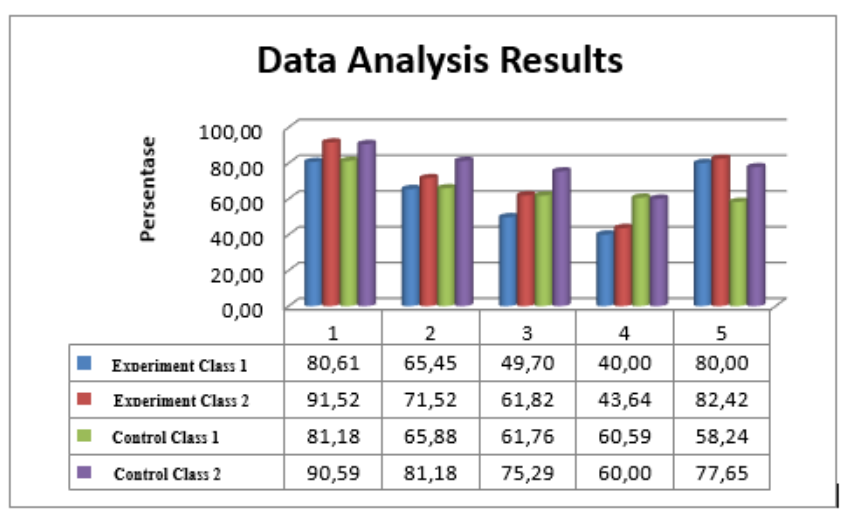

Picture 5.

Percentage of students' critical thinking skills in each aspect of critical thinking indicators

Learning activities of students assessed are activities in working on modules. Comparison of the learning activities of the experimental class 1 (low ability) and 2 (medium ability) can be seen in Picture 6.

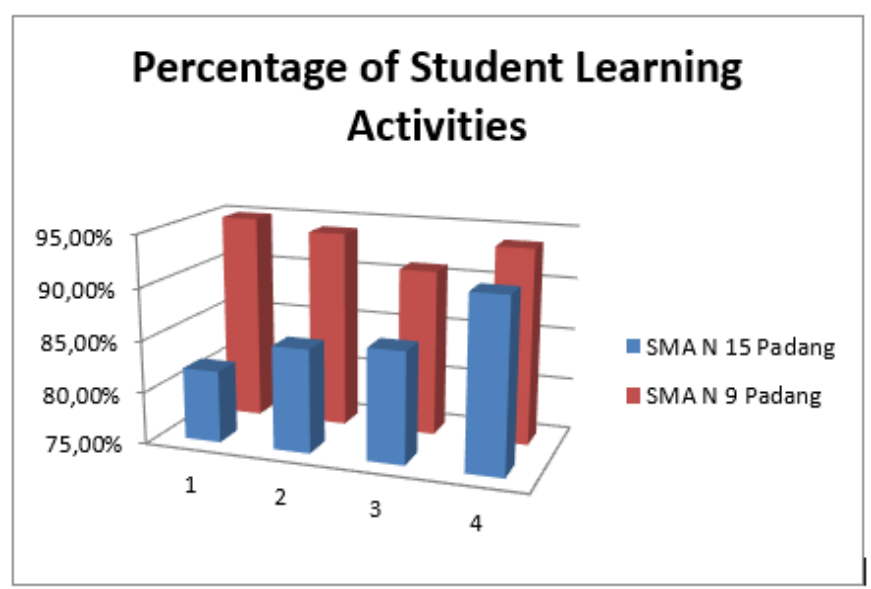

Picture 6.

Percentage of Student Learning Activities Using Modules

The first activity is observing pictures and written sources to formulate problems and hypotheses, obtained an average learning activity of students with effective categories for experimental class 1 and very effective categories for experimental class 2 . If students observe images and read information then they can formulate problem and write down the appropriate hypothesis. The second activity is answering questions in the module. In the data processing stage, students are guided by questions to find concepts. The answers given by the students were then assessed and the average learning activities of the students were obtained with a very effective category both for the experimental class 1 and for the experimental class 2 . The third activity was collecting information, obtained by the average activity of the students with a very effective category for the second experimental class. The fourth activity is to do the exercises contained in the worksheet. In the experimental class 1 and experimental class 2 obtained an average activity with the category Very effective. Overall the average percentage of student learning activities using modules has a very effective category, both in schools with high and low student abilities. This is because the learning activities in the module use the steps of discovery learning.

In each learning activity in the module there are critical thinking skills that are trained. Students' critical thinking skills are assessed by giving five critical thinking questions in the form of description. There are five aspects of critical thinking that are assessed, namely providing basic clarification, making the basis of a decision, making inferences, providing advanced clarification and managing strategies and tactics (strategy and tactics) (Ennis, 2011:2). 


\section{CONCLUSION}

Based on the results of research that has been done, the following conclusions are obtained:

The resulting product is a chemical module based on discovery learning redox reaction with probing prompting technique to improve the critical thinking skills of high school students in class $\mathrm{X}$.

The results of research that have been done show that: (a). The redox reaction chemistry module based on discovery learning with the probing prompting technique produced has a very high level of validity with a kappa moment value of 0.87 . (b) The practicality level of the resulting module is very high, in the small group evaluation questionnaire obtained kappa moment 0.93 , from the results of the questionnaire field trial phase (field test) obtained kappa moment 0.91 and from the results of the teacher questionnaire responses the kappa moment is 0.86 . (c). The effectiveness of the module can be seen from the comparison of student learning outcomes in the experimental class (learning by using modules) and in the control class (learning without using modules). Hypothesis testing shows that there is a significant difference between experimental class learning outcomes and control class learning outcomes with a $95 \%$ confidence level of significance $(\alpha) 0.05$ in schools with moderate student abilities and schools with low student abilities. (d). Hypothesis test results indicate that the module developed can improve students' critical thinking skills. In general, students' critical thinking skills in the experimental class are higher than those in the control class for both medium and low ability schools.

\section{REFERENCES}

[1]. Arikunto, Suharsimi. 2009. Manajemen Penelitian. Jakarta: Rineka Cipta. Boslaugh, Sarah dan Paul A.W. 2008. Statistics in A Nutshell, A Desktop Quick Reference. Beijing, Cambridge, Famham, Koln, Sebatopol, Taipei, Tokyo: O'reilly.

[2]. Chang, Raymond. 2010. Chemistry Tenth Edition. New York: The McGraw-Hill Companies, Inc.

[3]. Direktorat Tenaga Kependidikan. 2008. Penulisan Modul. Jakarta: Departemen Pendidikan Nasional.

[4]. Ellizar, 2012. Pengembangan Program Pembelajaran. Padang: UNP Press

[5]. Ellizar, Bayharti dan Andromeda. 2013. Pengaruh Motivasi dan Pembelajaran Kimia Menggunakan Modul dan Tanpa Modul terhadap Hasil Belajar Kimia di RSMA-BI. Prosiding Semirata FMIPA Universitas Lampung: 117-124.

[6]. Ellizar, E., Hardeli, H., Beltris, S., \& Suharni, R. (2018, April). Development of Scientific Approach Based on Discovery Learning Module. In $O P$ Conference Series: Materials Science and Engineering (p. 012101).

[7]. Ellizar, E., Putri, S. D., Azhar, M., \& Hardeli, H. (2019, April). Developing a discovery learning module on chemical equilibrium to improve critical thinking skills of senior high school students. In Journal of Physics: Conference Series (Vol. 1185, No. 1, p. 012145). IOP Publishing.

[8]. Elsa. 2015. Penerapan Model Pembelajaran ProbingPrompting untuk Meningkatkan Kemampuan Berpikir Kritis Matematis Siswa Kelas XI IPA MAN 1 Kota Bengkulu”. Jurnal Pendidikan Matematika Raflesia,2 (1): $97-100$

[9]. Ennis, Robert H. 1990. "Goals for A Critical Thinking Curriculum"; dalam Costa, Arthur L. 1991. Developing Minds: A Resource Book for Theaching Thinking. Alexandria: Association for Supervision and Curriculum Development.

[10]. Ernica, S. Y., \& Hardeli, H. (2019). VALIDITAS DAN PRAKTIKALITAS E-MODUL SISTEM KOLOID BERBASIS PENDEKATAN SAINTIFIK. Ranah Research: Journal of Multidisciplinary Research and Development, 1(4), 812-820.

[11]. Isworini, Sunarno, W., dan Sulistyo, S., 2015. Pengembangan Modul Pembelajaran Hidrolisis Garam Berbasis Model Inkuiri terbimbing Untuk Siswa Madrasah Aliyah Kelas XI, Jurnal Inkuiri, 4(3): 9-20

[12]. Johnson, Elaine B. 2002. Contextual Teaching and Learning: Menjadikan Kegiatan Belajar Mengajar Mengasyikkan dan Bermakna. Terjemahan oleh Ibnu Setiawan. 2006. Bandung: Penerbit MLC.

[13]. Nasution. 2015. Berbagai Pendekatan dalam Proses Belajar dan Mengajar Jakarta: Bumi Aksara.

[14]. Nieveen, Nienke. 1999. Design Approaches and Tools in Education and Training. Netherlands: Kluwer Academic Publishers.

[15]. Plomp, Tjeerd dan Nienke Nieveen. 2013. Educational Design Research: An Introduction. Enschede: Netherlands Institute for Curriculum Development (SLO).

[16]. Prastowo, Andi.2014. Pengembangan Bahan Ajar Tematik: Tinjauan Teoritis dan Praktik. Jakarta: Kencana.

[17]. Shoimin.2016. Model Pembelajaran Inovatif. Dalam Kurikulum. 2013. Yogjakarta: Ar-ruzz Media

[18]. Zubaidah, Corebima, Mistianah. 2015. Asesmen Berpikir Kritis Terintegrasi TesEssay. Symposium on Biology Education: 200-213

[19]. Zivkovic, Sladana. 2016. A Model of Critical Thinking as an Important Attribute for Success in the 21st Century. Procedia Social and Behavioral Sciences. 232: $102-108$. 